\title{
Hydrocarbon gases in Palaeogene volcanic rocks from the Lopra-1/1 A well, Faroe Islands
}

\author{
Troels Laier
}

Hydrocarbon gases were monitored in the drilling fluid during deepening of the Lopra- 1 well from 2178-3565 m, in which thermogenic, methane-rich gases had been found previously. The mud gas concentration, up to $10^{5} \mathrm{ppm}$ of methane, was generally higher in the hyaloclastite sequence, $2470 \mathrm{~m}-$ terminal depth (TD), than in the overlying lavas of the lower basalt formation. The highest concentrations of mud gas in the lower basalt formation were associated with the more porous tuffaceous zones, whereas no simple relationship could be established between measured mud gas concentrations and porosity of the hyaloclastic rocks, which showed less marked porosity variations than the lavas.

Chemical $\left(\mathrm{C}_{2+}<1 \%\right)$ and isotopic $\left(\delta^{13} \mathrm{C}_{1}\right.$ : -34 to $-39 \%$ ) compositions of seven samples of mud gas collected at peak gas concentrations between $2657 \mathrm{~m}$ and $3442 \mathrm{~m}$ compare well with those of the hydrocarbon gases which had been seeping more or less continuously into the existing well since 1983 , suggesting a common origin of the gases.

Headspace methane concentrations measured in 135 canned samples of cuttings were scattered between $10 \mathrm{ppm}$ and $6 \times 10^{3} \mathrm{ppm}$, with the exception of six samples from a short interval, 2685$2745 \mathrm{~m}$, which showed consistently high values $>10^{4} \mathrm{ppm}$. No particularly gas-rich zones were indicated, however, by the mud gas, nor was any significant change in lithology noted for this interval. It is possible that the technique of turbo-drilling, that had been attempted over a short interval, 2657$2675 \mathrm{~m}$ prior to collection of the high-level methane samples, may have caused enhanced degassing due to the very fine cuttings produced. Chemical and isotopic composition of headspace gas and mud gas indicated the same type of gas throughout the well, although headspace methane tended to be more enriched with respect to the ${ }^{13} \mathrm{C}$ isotope.

The origin of the Lopra-1 gas is discussed in the light of recent information obtained from source rock studies of central East Greenland and the Faroe-Shetland Basin.

Keywords: Faroes, Lopra-1/1A, volcanics hydrocarbon gas, isotopes, headspace methane, cuttings

Geological Survey of Denmark and Greenland, Øster Voldgade 10, DK-1350 Copenhagen K, Denmark. E-mail: tl@geus.dk

As hydrocarbons were not expected to occur in the basalts of the Faroe Islands, no monitoring of hydrocarbon gases in the drilling fluid was performed while drilling the 2178 $\mathrm{m}$ deep scientific Lopra-1 well in 1981. A few observations made while drilling, however, indicated negligible amounts of gases in the basalts (Waagstein et al. 1984). None of these observations suggested larger accumulations of gas so, after having reached TD in November 1981, the drilling fluid in the well was replaced by fresh water. Soon afterwards, the well began to flow approximately
9.5 litres/min. (K. Højgård, personal communication 1982) and it was decided after a few days to shut-in the well. The Lopra-1 well was not re-opened until March 1983, when temperature logging was to be performed. By that time the wellhead pressure had increased to 19.5 bars (Balling et al. 1984) and an inflammable gas had accumulated within the $190 \mathrm{~m}$ long casing at the top of the well (P.H. Nielsen, personal communication 1983). The volume of the gas was estimated to be roughly $9 \mathrm{~m}^{3}$ at 1 bar pressure (P.H. Nielsen, personal communication 1983) 


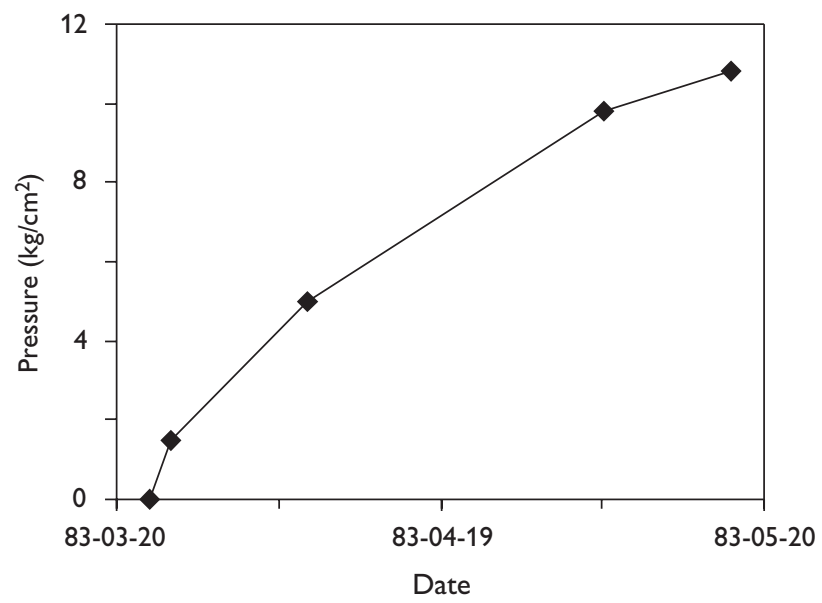

Fig. 1. Wellhead pressure of the Lopra-1 well during the shut-in period after temperature logging (P.H. Nielsen, personal communication 1983).

and gas chromatographic analysis of a sample collected at the wellhead showed the gas to consist of methane (72\%) and nitrogen $(27 \%)$ plus traces of higher hydrocarbons (Jacobsen \& Laier 1984). After temperature logging, the well was shut-in again and an increase in wellhead pressure was noted shortly after. Two months later, the wellhead pressure had increased to 10.8 bars (Fig. 1). Collection of a new gas sample showed that the composition of the gas was almost identical to that of the sample collected two months earlier. Furthermore, isotopic analyses indicated that the gas was thermogenic in origin, the $\delta^{13} \mathrm{C}$ of methane being -39.6\% (Jacobsen \& Laier 1984).

Encouraged by the hydrocarbon discoveries of Foinaven in 1992 and Schiehallion in 1993 in the British sector $160 \mathrm{~km}$ south-east of the Faroe Islands, new investigations of the hydrocarbon traces in the Lopra-1 well were carried out in 1992-1993, including stable isotopic analysis of gases and biomarker analyses of the small quantities of higher hydrocarbons extracted from the water flowing out of the well (Laier et al. 1997). An additional gas sample was taken for isotopic analysis in July 1994, before the deepening of the Lopra-1 well commenced in July 1996 (Table 1).
This paper presents the results of new chemical and isotopic analyses of both mud gas samples and headspace gas of canned cuttings collected during a deepening of the Lopra-1/1A well in 1996. The results of the continuous mud gas readings are compared with well logs in order to identify any particular gas-rich zones, and the possible origin of the hydrocarbon gases in the basalts is discussed.

\section{Sampling and methods}

\section{Mud gas}

Gas samples were taken at the mud-logging unit on different occasions (Table 2). The gas samples were stored in $100 \mathrm{~cm}^{3}$ steel bottles which had been flushed with mud gas for two minutes before closing the valves. The samples were sent to the Geological Survey of Denmark and Greenland (GEUS) within a week for chemical and isotopic analyses.

The concentrations of hydrocarbon gases in the gas samples were analysed using a Shimadzu GC9 gas chromatograph equipped with a flame ionisation detector (FID). Separation of the gas constituents was performed on a $4 \mathrm{~m} 1 / 8$ " diameter SS column packed with silica gel $70 / 80$ mesh using helium as carrier gas $(20 \mathrm{ml} / \mathrm{min}$.) using a temperature programme beginning at $100^{\circ} \mathrm{C}$, increasing $20^{\circ} \mathrm{C} / \mathrm{min}$. to $250^{\circ} \mathrm{C}$ final temperature.

\section{Headspace gas of canned cuttings}

Unwashed cuttings were sampled at approximately $10 \mathrm{~m}$ intervals and stored in 0.5 litre cans to which bactericide had been added. The cans were sent to GEUS for headspace gas and isotopic analyses after the completion of the well. The cans were generally in a good condition when received by GEUS, except for a few cans where the lid was not sealed tightly. The cans were placed upside down, punctured through a septum and $0.2 \mathrm{ml}$ of headspace gas

Table 1. Chemical and isotopic composition of gases from the original Lopra-1 well collected at the wellhead

\begin{tabular}{rrrrrrrrrrrrrrr}
\hline Year & $\mathrm{CH}_{4}$ & $\mathrm{C}_{2} \mathrm{H}_{6}$ & $\mathrm{C}_{3} \mathrm{H}_{8}$ & $\mathrm{iC}_{4} \mathrm{H}_{10}$ & $\mathrm{nC}_{4} \mathrm{H}_{10}$ & $\mathrm{~N}_{2}$ & $\mathrm{O}_{2}+\mathrm{Ar}$ & $\mathrm{CO}_{2}$ & $\mathrm{H}_{2}$ & $\delta^{13} \mathrm{C}_{1}$ & $\delta^{13} \mathrm{C}_{2}$ & $\delta^{13} \mathrm{C}_{3}$ & $\delta \mathrm{D}_{1}$ \\
\hline 1994 & 60.2 & 0.31 & 0.048 & 0.014 & 0.012 & 39.1 & 0.06 & 0.01 & $<0.01$ & -39.9 & -32.1 & -26.5 & -150 \\
1992 & 40.6 & 0.14 & 0.025 & 0.008 & 0.007 & 59.1 & n.d. & 0.01 & $<0.01$ & -41.5 & -32.4 & -26.5 & -148 \\
1983 & 1.9 & 0.41 & 0.064 & 0.015 & 0.018 & 27.5 & 0.04 & 0.01 & $<0.01$ & -39.6 & -32.5 & n.a. & -133 \\
\hline
\end{tabular}

n.a.: not analysed; n.d.: not determined. Concentrations are given in vol\%. Stable isotopic ratios are given (in parts per thousand) relative to the Pee Dee Belemnite (PDB) and Standard Mean Ocean Water (SMOW) standards. 
Table 2. Drilling events which may influence hydrocarbon gas measurements

\begin{tabular}{|c|c|c|}
\hline Interval $(\mathrm{m})$ & Event & Comments \\
\hline $2360-2450$ & $\begin{array}{l}\text { Sour smell and low } \\
\mathrm{pH} \text { of drilling fluid }\end{array}$ & $\begin{array}{l}\text { Indication of bacterial activity. Bacteria may generate/consume methane. } \\
\text { Low } \mathrm{pH} \text { may cause corrosion and generation of artificial gas. }\end{array}$ \\
\hline $2657-2675$ & Turbo drilling & $\begin{array}{l}\text { Finer cuttings. Possible enhanced degassing. Potential risk of gas generation due to high } \\
\text { temperature. }\end{array}$ \\
\hline $2680-2822$ & $\begin{array}{l}\text { One shale shaker } \\
\text { out of order }\end{array}$ & Specific gravity increase, $1.11-1.18 \mathrm{~g} / \mathrm{cm}^{3}$, of drilling fluid due to solids build-up. \\
\hline 2992 & $20 \%$ dilution of mud & Reduction of specific gravity, $1.18-1.13 \mathrm{~g} / \mathrm{cm}^{3}$. \\
\hline 3023 & Mud centrifuge installed & Reduction of specific gravity to $1.06-1.08 \mathrm{~g} / \mathrm{cm}^{3}$. \\
\hline 3158 & String got stuck & $5 \mathrm{~m}^{3}$ diesel pill added. \\
\hline $3091-3565$ & Side track, Lopra-1A & $1 \%$ oil in drilling fluid according to daily analysis. \\
\hline
\end{tabular}

was withdrawn using a gas-tight syringe to be analysed by gas chromatography as described above. If a high concentration of methane was found, $60 \mathrm{ml}$ of headspace gas was transferred to an evacuated serum bottle for later isotopic analysis. The volume of headspace gas in the cans, generally between $100-150 \mathrm{ml}$, was checked by addition of water. No corrections on headspace gas concentrations were attempted to account for the difference in headspace volumes.

\section{Isotopic analyses}

Headspace gas and mud gas samples were transferred to a $1 / 4$ ” column packed with Porepak Q immersed in liquid nitrogen. Separation of the gas constituents was then performed allowing the column to heat to ambient temperature. Methane and ethane were combusted over $\mathrm{CuO}$ at $900^{\circ} \mathrm{C}$ and the resulting carbon dioxide was isolated in flame-sealed glass ampoules using cryogenic traps. Isotopic measurements were performed on a Finnigan Mat 251 mass spectrometer at the University of Copenhagen.

The isotopic ratio is expressed in the usual delta notation relative to the PDB standard.

$$
\delta^{13} \mathrm{C}(\% 0)=\left(\mathrm{R}_{\text {sample }} /\left(\mathrm{R}_{\text {standard }}-1\right)\right) \times 1000
$$

where

$$
\mathrm{R}={ }^{13} \mathrm{C} /{ }^{12} \mathrm{C}
$$

The analytical precision of the isotopic measurements is \pm $0.2 \%$ for larger quantities of gas ( $>20 \mu \mathrm{CO}_{2}$ STP), typical of the amounts of methane in all of the analysed samples, and $\pm 0.5 \%$ o for smaller quantities of gas $(<10$ $\mu \mathrm{l} \mathrm{CO} \mathrm{CO}_{2}$ STP), typical of the ethane.

\section{Results and discussion}

\section{Gases from the original Lopra-1 well}

No casing had been set in the old Lopra-1 well except for the upper $190 \mathrm{~m}$ of the borehole. Therefore, the substantial amount of gas which had accumulated at the wellhead during the 16 months shut-in period after drilling, could in theory have entered from any part of the open hole. However, Jacobsen \& Laier (1984) observed an increase in the gas to water ratio with depth suggesting that the gas entered mainly in the deeper parts of the well. The flow of gas ( $0.8 \mathrm{litre} / \mathrm{min}$., ambient pressure and temperature) from the well measured by Jacobsen \& Laier (1984) during their field work in June 1983 also suggested that the gas continued to seep into the open borehole of the Lopra-1 well. Taking into account the methane dissolved in the water flowing out of the well (at a water flow rate of 12.8 litres $/ \mathrm{min}$.), the total flow of methane is estimated to have been approximately 0.9 litre $/ \mathrm{min}$.; 0.56 litre $/ \mathrm{min}$. in the gas phase $\left(72 \% \mathrm{CH}_{4}\right)$ plus 0.3 litre/min. dissolved in water. So the total flow of methane in June 1983 was over $1 \mathrm{~m}^{3}$ per day. If the influx of methane had been the same during the initial 16 months shut-in period, a much larger quantity of gas would be expected than the $9 \mathrm{~m}^{3}$ (ambient pressure) noted when the well was re-opened in March 1983. However, the flux may have been slower during the shut-in period due to higher pressure (19.5 bars) at the wellhead.

Gas was still seeping into the borehole 13 years after drilling of the Lopra-1 well. The composition of the hydrocarbon gas had not changed significantly during that period (Table 1) and this suggests a major single source of the gas. The source provided mainly methane, as the nitrogen content in the gas-to-water ratio measured at well- 


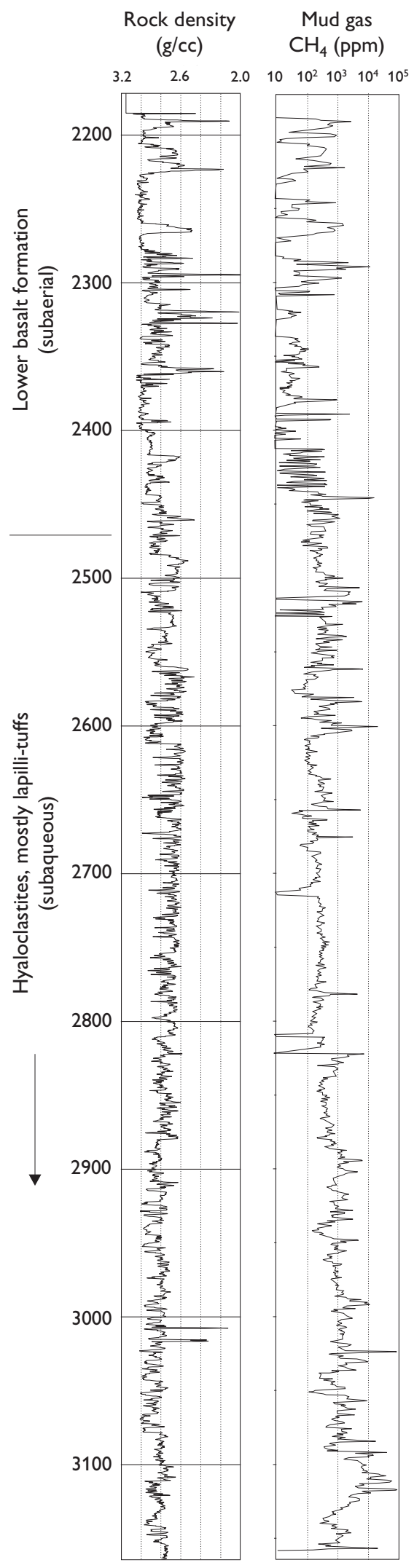

head can be accounted for by the amount of atmospheric nitrogen initially dissolved in meteoric water $\left(\right.$ at $\left.6^{\circ} \mathrm{C}\right)$ percolating into the basalts.

\section{Mud gas from the Lopra-1/1A deepening}

The original Lopra-1 well, drilled in 1981, was deepened in 1996. A $75 / 8$ " casing was first set in the existing $81 / 2$ " borehole before the well was extended downwards using a $61 / 2$ " drill bit. The Lopra- 1 well was terminated at $3158 \mathrm{~m}$ due to technical problems and a sidetrack was drilled from $3095 \mathrm{~m}$ to a TD of $3565 \mathrm{~m}$ (Lopra-1A). Any hydrocarbons detected in the drilling fluid or in the sealed samples of drill cuttings of the extended well section must have come from the new drilling activities. No casing was set in the new well sections, which means that gases detected in the drilling fluid (Fig. 2) represent the sum of gases released by drilling in addition to the gases that may have

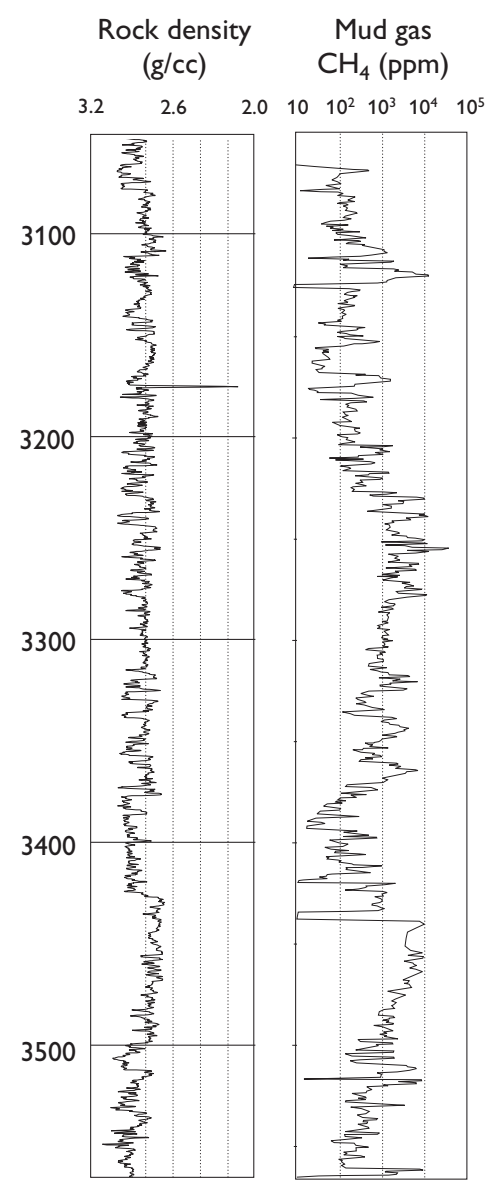

Fig. 2. Rock density and mud gas recorded in the extended Lopra-1/1A well. 
seeped through the sidewall of the entire open hole. A $\mathrm{KCl}$-polymer mud was used as drilling fluid and the well logs indicate that no substantial mud cake had been built up in the hole. Therefore, gas seepage from the sidewall of the open hole was probably more significant for the Lopra-1/1A well compared to conventional exploration wells in sedimentary rocks.

The mud gas and headspace gas data from the Lopra$1 / 1 \mathrm{~A}$ well are the only information available on hydrocarbon gases in the basalts penetrated, as no further tests were performed in the well after drilling. Drilling was optimised to detect hydrocarbon gases in the rocks penetrated, i.e. the specific gravity of the drilling fluid was kept low and the trap for continuous hydrocarbon measurement was placed in an almost closed mudline system. However, the mud gas and headspace gas must be interpreted with caution. It is important to consider any possible effects of the drilling process itself. The drilling events which may have influenced the hydrocarbon measurements and which could give a false impression of the hydrocarbon variation in the rocks, have been listed in Table 2, together with their possible implications.

The specific gravity of the mud could not be kept constant until a centrifuge had been installed (when drilling had reached $3023 \mathrm{~m}$ ), after which the specific gravity remained at $1.06-1.08 \mathrm{~g} / \mathrm{cm}^{3}$. During drilling of the lower basalt formation from 2184 to $2470 \mathrm{~m}$ the specific gravity remained almost constant at $1.03-1.05 \mathrm{~g} / \mathrm{cm}^{3}$. At greater depths, the cuttings became finer and the specific gravity of the mud was increased gradually to $1.18 \mathrm{~g} / \mathrm{cm}^{3}$ at $2992 \mathrm{~m}$ by increasing the content of solids. An increase in mud weight suppresses degassing from the rocks, which lowers the gas concentration in the mud. On the other hand, an elevated solids content may increase gas concentration, depending on how fast the cuttings degas. With these uncertainties in mind, a more detailed interpretation of the mud gas will be presented below.

Mud gas concentration varied from less than $10 \mathrm{ppm}$ to $90000 \mathrm{ppm}$ of methane down to $3120 \mathrm{~m}$ depth, showing a general increase from $2400 \mathrm{~m}$ to $3120 \mathrm{~m}$ (Fig. 2). Higher hydrocarbons, mostly ethane, constituted less than one percent of the total gas throughout the drilling of the well and will not be dealt with in detail in the following. The intervals with very low mud gas concentrations, $<10$ ppm, were observed only in the lower basalt formation above $2470 \mathrm{~m}$. Comparing mud gas concentration versus depth with various well logs as well as changes in various drilling parameters (rate of penetration, mud density etc.) it appears that rock porosity and rock density are the most important rock properties affecting the mud gas concentration in the upper $300 \mathrm{~m}$ of the extended well (Fig. 2).
Table 3. Samples of mud gas collected from the Lopra-1/1A well on various occasions

\begin{tabular}{|c|c|c|c|}
\hline $\begin{array}{l}\text { Sample } \\
\text { No. }\end{array}$ & Date & $\begin{array}{c}\text { Depth } \\
(\mathrm{m})\end{array}$ & Event \\
\hline 1 & $96 / 08 / 28$ & 2657 & $\begin{array}{l}\text { Resumed mud circulation } \\
\text { after changing of drill bit }\end{array}$ \\
\hline 2 & $96 / 09 / 07$ & 2822 & $\begin{array}{l}\text { Resumed mud circulation } \\
\text { after changing of drill bit }\end{array}$ \\
\hline 3 & $96 / 09 / 09$ & 2946 & $\begin{array}{l}\text { Gas collected after short } \\
\text { drilling break }\end{array}$ \\
\hline 4 & $96 / 09 / 10$ & 2989 & $\begin{array}{l}\text { Gas collected at peak con- } \\
\text { centration while drilling }\end{array}$ \\
\hline 5 & $96 / 09 / 19$ & 3107.5 & $\begin{array}{l}\text { Gas collected at peak con- } \\
\text { centration while drilling }\end{array}$ \\
\hline 6 & $96 / 10 / 23$ & 3343 & $\begin{array}{l}\text { Gas collected at peak con- } \\
\text { centration while drilling }\end{array}$ \\
\hline 7 & $96 / 10 / 26$ & 3442 & $\begin{array}{l}\text { Gas collected after having } \\
\text { drilled } 6 \mathrm{~m} \text { after trip }\end{array}$ \\
\hline
\end{tabular}

Variations in rock density and porosity correlate closely, so only the most complete log, the density log, is shown on Fig. 2. Assuming that the gas is indigenous to the rock and not an artefact of drilling, the highest gas concentrations should be found in the more porous, less dense rocks, as is also indicated by the data for the upper $300 \mathrm{~m}$ of the extended Lopra-1/1A well. However, this simple relationship is not observed for the deeper parts of the well. From $2610 \mathrm{~m}$ to $3080 \mathrm{~m}$ the density of the rock generally increases and porosity decreases, yet a general increase in mud gas concentration is observed in this same interval, an increase that may be explained by the increased sidewall surface area. This suggests that degassing through the sidewall of the hole contributes more to the mud gas compared to the gas released by the drilling process itself.

The presumed gas seepage through the sidewall of the open hole makes it difficult to decide which part of the well actually contributes to the gases recorded in the mud. However, for the deepest part of the well, below $3430 \mathrm{~m}$, changes in the mud gas concentration appear to be correlated positively with porosity (and inversely with rock density), which may indicate that gas is present even in the deepest rocks penetrated by the Lopra-1/1A well. Thus, it may be concluded that hydrocarbons are most likely present in all of the rocks penetrated, particularly in the more porous rocks. However, no particular hydrocarbon-rich zones and no cap rock were identified.

Samples of mud gas were collected at maximum gas concentrations as far as possible (Table 3). Three of the samples were taken when mud circulation was resumed after changing the drill bit, and the rest of the samples were taken at maximum concentration while drilling. The 
Table 4. Chemical and isotopic composition of mud gas samples

\begin{tabular}{lrlllllll}
\hline $\begin{array}{l}\text { Depth } \\
(\mathrm{m})\end{array}$ & $\begin{array}{c}\mathrm{CH}_{4} \\
\mathrm{Ppm}\end{array}$ & $\begin{array}{c}\mathrm{C}_{2} \mathrm{H}_{6} \\
\mathrm{Ppm}\end{array}$ & $\begin{array}{c}\mathrm{C}_{3} \mathrm{H}_{8} \\
\mathrm{Ppm}\end{array}$ & $\begin{array}{c}\mathrm{iC}_{4} \mathrm{H}_{10} \\
\mathrm{Ppm}\end{array}$ & $\begin{array}{c}\mathrm{nC}_{4} \mathrm{H}_{10} \\
\mathrm{Ppm}\end{array}$ & $\begin{array}{c}\delta^{13} \mathrm{C}_{1} \\
(\% \circ)\end{array}$ & $\begin{array}{c}\delta^{13} \mathrm{C}_{2} \\
(\% \circ)\end{array}$ & $\mathrm{C}_{1} / \mathrm{C}_{2}$ \\
2657 & 4420 & 31.6 & 4.06 & 0.44 & 0.63 & -38.6 & -31.8 & 140 \\
2822 & 4820 & 31.7 & 3.02 & n.d. & n.d. & -38.2 & -35.0 & 152 \\
2946 & 2400 & 19.0 & 1.56 & n.d. & n.d. & -36.7 & n.a. & 126 \\
2989 & 10440 & 81.6 & 6.78 & 0.36 & 0.40 & -37.3 & -32.3 & 128 \\
3107.5 & 10200 & 74.4 & 9.34 & 0.92 & 1.36 & -38.1 & -33.4 & 137 \\
3343 & 2740 & 17.3 & 3.44 & 0.66 & 1.10 & -34.2 & n.a. & 158 \\
3442 & 4290 & 28.4 & 5.86 & 0.98 & 1.45 & -36.0 & -33.6 & 151 \\
\hline
\end{tabular}

n.d.: not detected. n.a.: not analysed.

concentrations of hydrocarbon gases in the mud gas samples were usually lower compared to mud gas concentrations recorded in the mud by the time of sampling (Table 4 ) although the chemical composition of the gas was the same. The reason for this is not clear, but insufficient flushing of the $100 \mathrm{cc}$ steel bottle during sampling could be one reason. The chemical and isotopic composition of the mud gas (Table 4) is not very different from that of the wellhead gas collected from the old Lopra-1 well (Table 1) suggesting a common origin for the gases.

\section{Headspace gas of sealed cuttings}

Methane concentration in the headspace gas of the 135 canned samples of cuttings from the Lopra-1/1A well varied from 7 ppm to over 33000 ppm, the highest concentrations being measured at $2273 \mathrm{~m}$ and in the interval from 2685 to $2745 \mathrm{~m}$ (Fig. 3). The sample at $2273 \mathrm{~m}$ was collected just after drilling through a 2-3 m thick layer of lapilli tuff with a distinctly higher porosity compared to the massive lavas above and below. A higher mud gas concentration was also noted for this porous layer (Fig. 2). The methane concentration in the samples from the 2685$2745 \mathrm{~m}$ interval is more than one order of magnitude higher than that of most other samples from the well. This interval corresponds to the upper part of a section of dominantly lapilli tuff (2610-2880 m) and could indicate that these rocks contain more gas than those at other levels. However, the mud gas concentration did not shift to higher values as one might have expected if the gas content was generally much higher in the rocks of this particular interval (Fig. 3). Furthermore, the well logs show no correlation between the increase in headspace methane and any change in rock properties, such as porosity or density. A shift from rotary drilling to turbo-drilling using a diamond bit took place at $2657 \mathrm{~m}$, and turbo-drilling continued to $2675 \mathrm{~m}$ where rotary drilling was resumed. Cuttings produced by turbo-drilling are generally much smaller than cuttings produced by normal rotary drilling. It is possible that the decrease in cutting size may have led to enhanced degassing and thereby higher headspace methane concentrations. Furthermore, one of the two shale shakers was out of order due to motor failure during drilling from 2680 to $2822 \mathrm{~m}$. This may be one of the reasons for the observed build up of solids in the drilling fluid, which, combined with the finer cuttings produced by turbo-drilling, may have been the cause of the significantly higher methane concentrations in the headspace gas.

Alternatively, the much higher concentration of methane measured in the headspace gas shortly after turbodrilling could be explained by generation of artificial gas due to the very high temperatures which often occur using this drilling technique. If, however, the gases were generated by some artificial process, an increase in mud gas methane concentration should be expected, which is not the case (Fig. 3). Furthermore, the stable isotopic ratio of the methane is not markedly different in the zone with high methane concentrations compared to headspace methane from other levels (Fig. 3).

Ethene, with concentrations up to $39 \mathrm{ppm}$, was observed in a number of headspace samples, particularly from the upper $300 \mathrm{~m}$ of the extended well where the $\mathrm{pH}$ of the drilling fluid was relatively low (7-8 compared with a typical value of 10) according to the daily drill reports. Unsaturates like ethene are very uncommon among light hydrocarbons in natural gas, so this constituent was most likely formed artificially, either during drilling (Faber $e t$

\section{Facing page:}

Fig. 3. Summary of mud gas and headspace results of the extended Lopra-1 well (A) and Lopra-1A sidetrack (B). Larger circles represent $C_{1} / C_{2}$ ratio corrected for artificial gas indicated by ethene $\left(C_{2}=\right)$. Numbers are stable isotopic values of methane. 
A

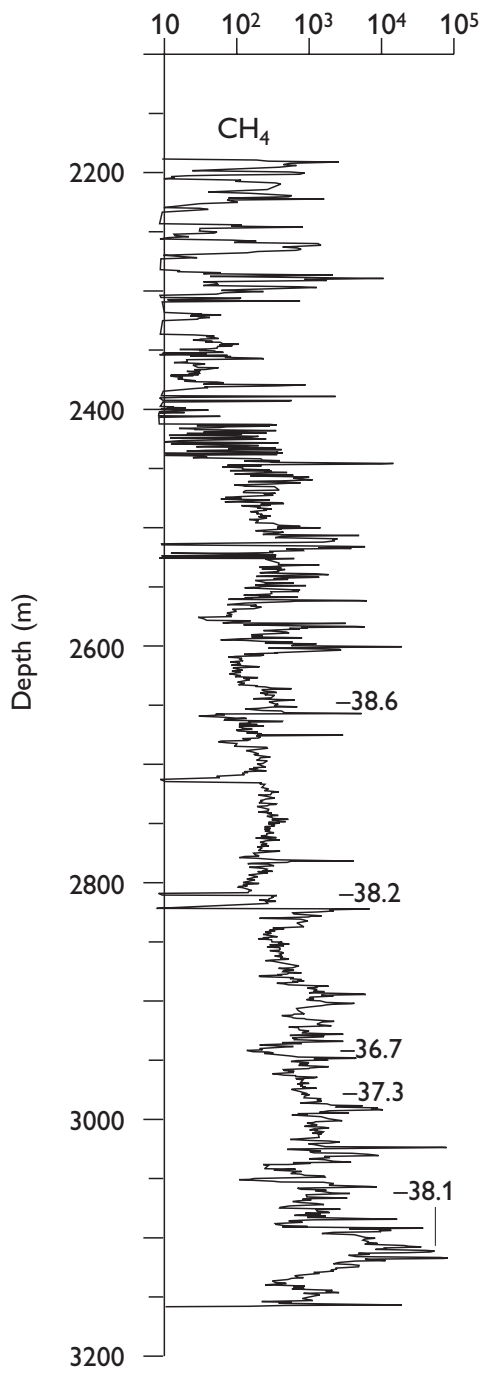

B

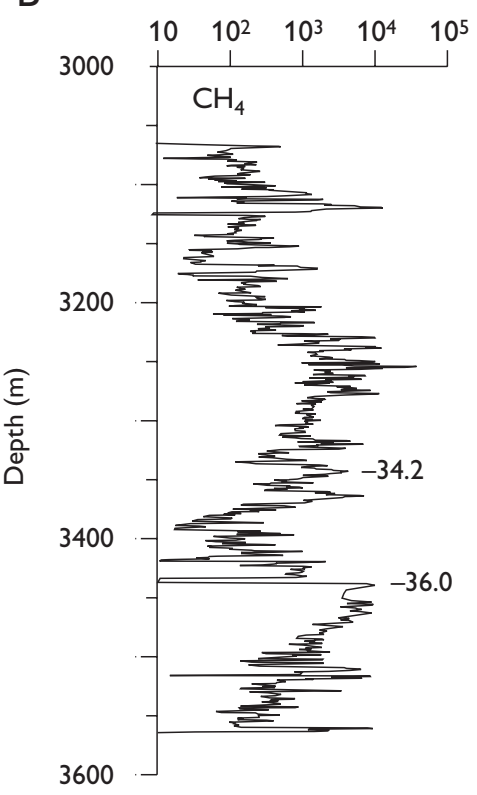

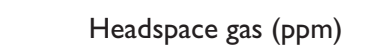
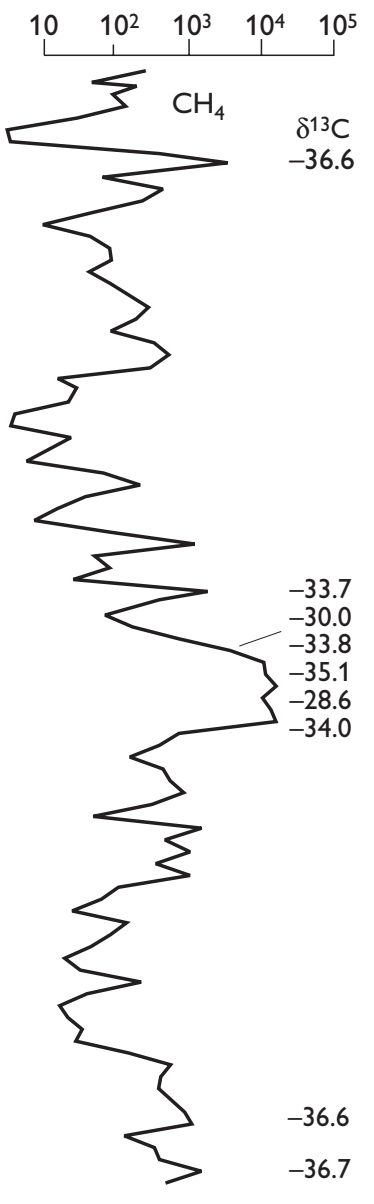

Headspace gas

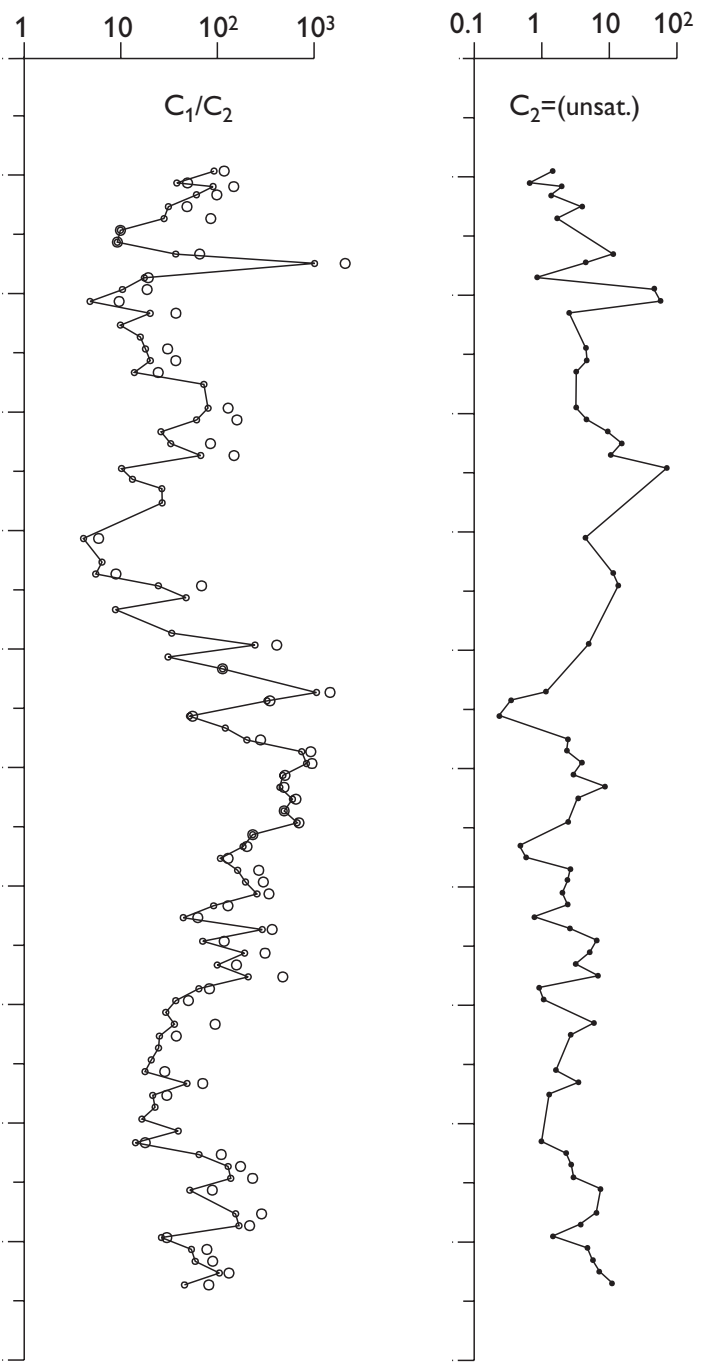

Headspace gas

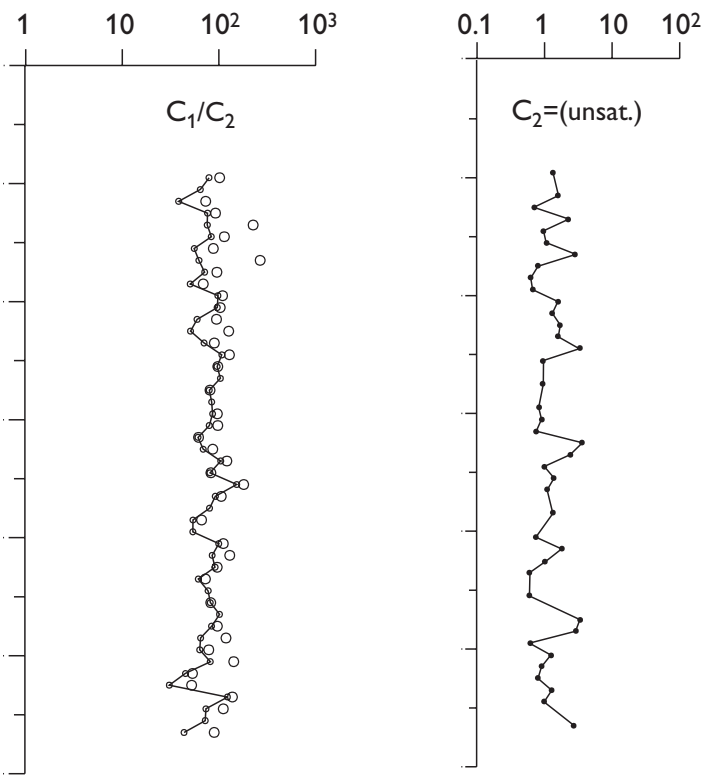


al. 1988) or as a result of corrosion (Laier 1999). Samples of cuttings generally contain iron filings from the drilling. Unsaturates can be generated by a catalytic reaction of the Fischer-Tropsch type, and may occur in canned cuttings with relatively low $\mathrm{pH}$, as was demonstrated for the Swedish deep gas well at Lake Siljan (Laier 1999). The concentration of ethene decreased when $\mathrm{pH}$ had been raised to over 10, by adding caustic soda and bactericide to the drilling fluid below $2500 \mathrm{~m}$ (Fig. 3).

The methane-to-ethane ratio of the gas may be useful in determining the origin of the gas in the volcanics, but a correction should be made for the artificial gas which may influence this ratio. The methane-to-ethane ratio of artificial gas varied between 3-5 in the Siljan well (Laier 1999), which is much lower than that of the gases in the Lopra1/1A well (Fig. 3). Equal amounts of ethene and ethane were noted in the artificial gas of the Siljan well (Laier 1999); assuming a similar ratio of $1: 1$ for the artificial gas component in the Lopra headspace samples, a correction has been made (Fig. 3). Headspace samples with methane concentrations below $100 \mathrm{ppm}$ have generally lower methane-to-ethane ratios, but this cannot be taken as evidence of a different origin of the gas. This is more likely due to uncertainties of the headspace method as well as the analytical uncertainty for the very low ethane concentrations. The methane-to-ethane ratio varied between $10^{2}$ and $10^{3}$ for headspace gas samples with higher methane concentrations (> $100 \mathrm{ppm}$ ) that have less analytical uncertainty (Fig. 3). The methane-to-ethane ratio remained fairly constant, around $10^{2}$, in samples from the side track Lopra1A. Thus, given the uncertainties of the headspace method, it may be concluded that the hydrocarbon gas of the

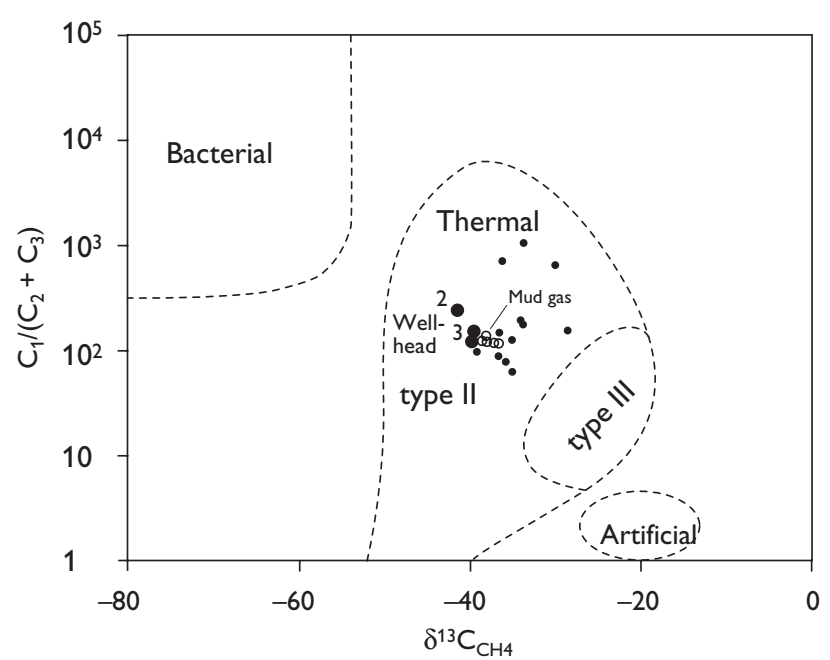

Fig. 4. Plot of $\mathrm{C}_{1} / \mathrm{C}_{2}+\mathrm{C}_{3}$ vs. $\delta^{13} \mathrm{C}_{\mathrm{CH} 4}$ for Lopra-1/1A gases. Small solid circles represent headspace gas. (Diagram modified from Faber et al. 1999.) sealed cuttings mainly has the same origin as that of the mud gas and the previous wellhead gas.

\section{Origin of the gasses}

The chemical and isotopic data for the gasses from the original Lopra-1 well and the extended well sections have been plotted in the well-known classification diagram for hydrocarbon gases (Fig. 4). The mud gas of the extended well plots fairly close to the wellhead gases of the old Lopra-1 well, suggesting that they have a common origin. Headspace gases, however, exhibit a much larger variation and are generally slightly more enriched with respect to carbon-13. Such enrichment could result from either bacterial oxidation of methane (Coleman et al. 1981) during storage or fractionation due to diffusion. The most carbon-13 enriched gases are found among the headspace samples with the highest methane concentration (Fig. 3), therefore bacterial oxidation is unlikely to have been responsible for the carbon-13 enrichment. If degassing from the cuttings occurred mainly via diffusion, the gas may have fractionated due to degassing prior to storage in the tight cans.

The hydrocarbon gases are thermogenic in origin, and the relatively low $\mathrm{C}_{2+}$ content indicates either a gas-prone source rock or a high maturity of the source rock. Comparing the stable isotope values $\left(\delta^{13} \mathrm{C}\right)$ of methane through propane (Tables 1,4 ) with the $\delta^{13} \mathrm{C}$ versus source maturity lines published by Rooney et al. (1995), a highly mature marine source rock (type II kerogen) is most likely for the Lopra gases. This is more obvious for the wellhead gases than for the mud gases as can be seen from Fig. 5. The larger variation in $\delta^{13} \mathrm{C}$ among the mud gas samples compared to the wellhead gases, particularly for ethane, may be due to the much smaller quantities of hydrocarbons making the mud gases more susceptible to sampling and analytical errors.

Rooney et al. (1995) estimated that the reservoir gases used to construct the $\delta^{13} \mathrm{C}$ versus maturity line for the type (II) kerogen had been generated in the temperature range $170-190^{\circ} \mathrm{C}$, the upper part of which is not very different from the maximum palaeotemperature estimated for the base of the Lopra-1/1A well (Glassley 2006, this volume). Furthermore, the reservoir gases used by Rooney et al. (1995), which had isotopic values in the same range as those of the Lopra-1 gases, were also very dry (M.A. Rooney, personal communication 2000). On the other hand, using $\delta^{13} \mathrm{C}$ versus source maturity lines constructed by other researchers such as Faber (1987) and Berner \& Faber (1996), a somewhat lower maturity is 


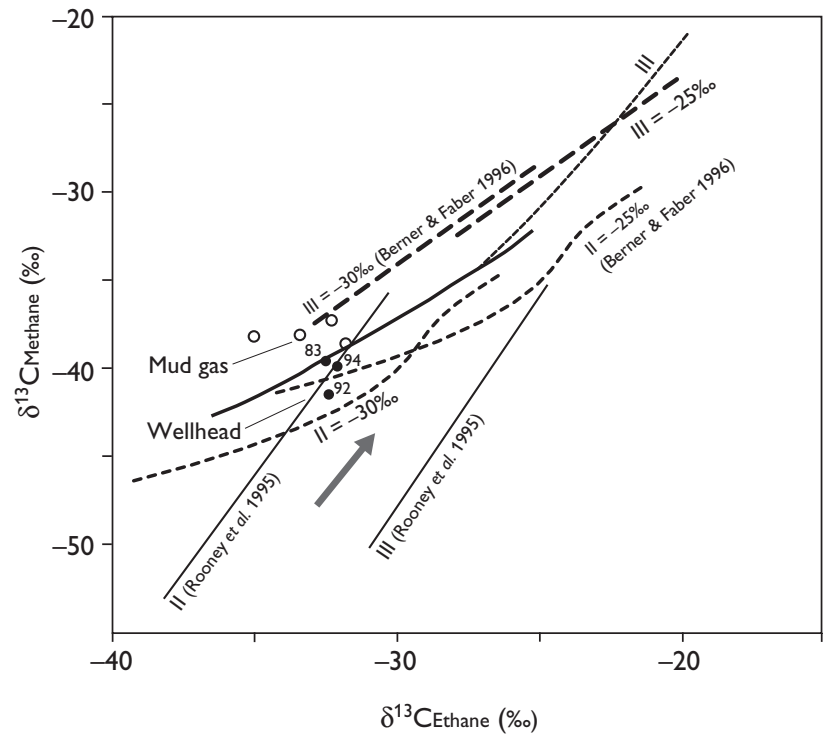

Fig. 5. Cross-plot of isotope values $\left(\delta^{13} \mathrm{C}\right)$ of methane vs. ethane of wellhead and mud gas samples from the Lopra-1/1A well. Maturity lines, from Faber (1987) and Rooney et al. (1995), were based on reservoir data, whereas those of Berner \& Faber (1996) were obtained from laboratory experiments. Numbers attached to wellhead samples refer to sampling year. predicted for the source of the Lopra-1 gases (Fig. 5). Therefore, the maturity of the source rock that generated the gases is still not certain.

The presence of a source rock is, however, very likely as was indicated by the continued and fairly significant flux of gas into the original Lopra-1 well over a 13-year period. The gases entering the open Lopra-1 well most likely came from the more porous layers of tuffs beneath the massive lavas of the lower basalt formation. No layers of coal were penetrated by the extended Lopra-1/1A well, so the source is most likely located below the hyaloclastites that were extruded subaqueously (Waagstein 2006, this volume).

\section{Traces of higher hydrocarbons}

The traces of higher hydrocarbons measured in mud samples derived mainly from various additives (Bojesen-Koefoed \& Nytoft 2006, this volume) and cannot give any clues as to the possible origin of the Lopra gases. Fluid inclusion studies by Konnerup-Madsen (2006, this volume) do, however, indicate that hydrocarbon fluids were present in the volcanics at one time. But analysis of a fluid extracted from one calcite sample containing fluid inclu-
Fig. 6. Pre-drift reconstruction of central East Greenland and the Faroes block, modified from L.M. Larsen et al. (1999). The arrow indicates the location of organic-rich sediments having Ro $=1.2 \%$ (M. Larsen, personal communication 2000).

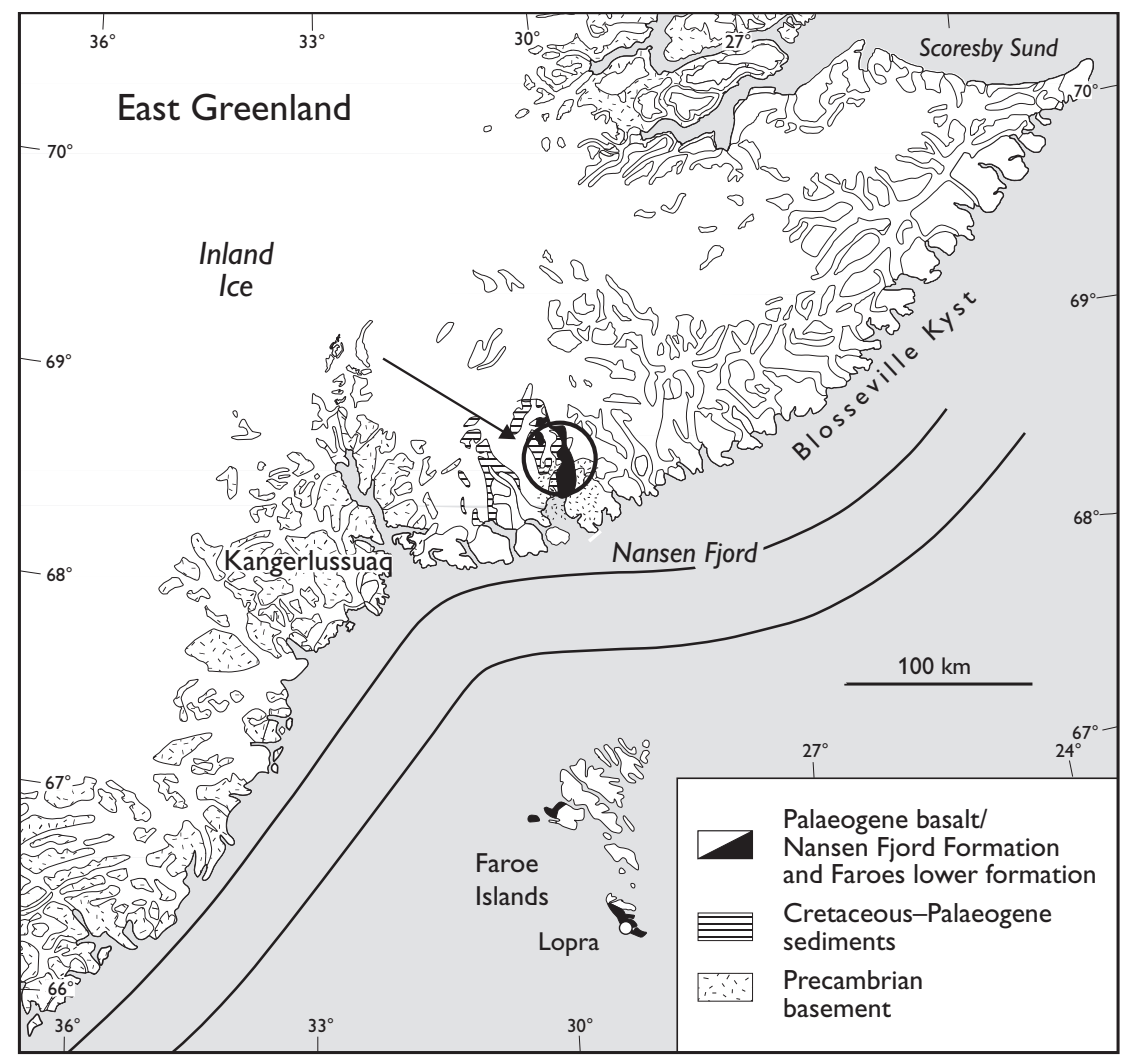




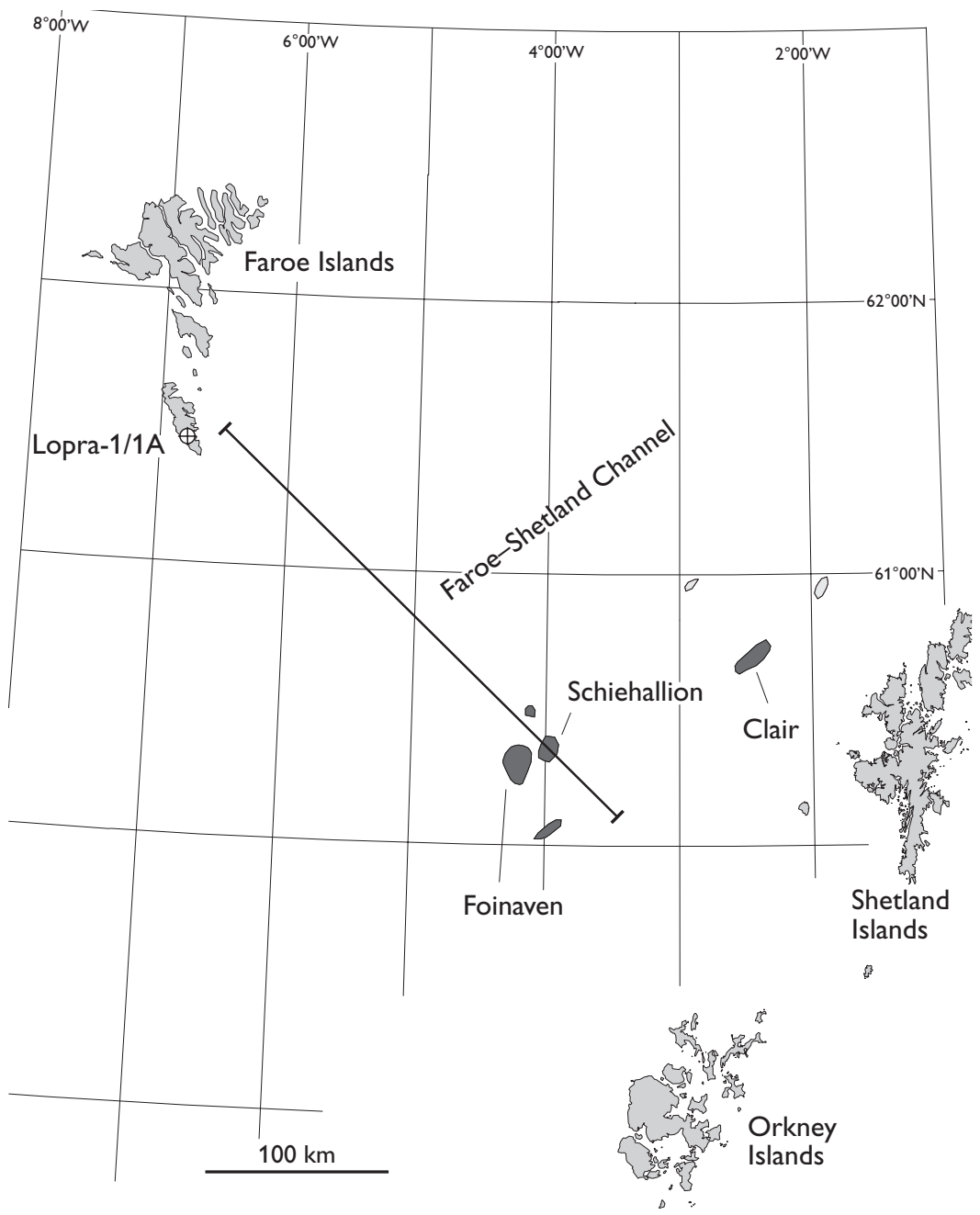

Fig. 7. Oil and gas fields west of Shetland.

sion could not be related unambiguously to a particular source (Bojesen-Koefoed \& Nytoft 2006, this volume).

Waxes associated with zeolites reported from other parts of the Faroe Islands (Laier et al. 1997) appeared to have been generated by a less mature source than that of the Lopra-1/1A gases. Thus, the presence of traces of higher hydrocarbons supports the assumption that hydrocarbons migrate or migrated in the volcanics of the area, but no direct connection between these higher hydrocarbons and the Lopra gases have been documented.

\section{Source rocks of the Faroe Islands area}

The scientific Lopra-1 drilling was termined in November 1981 at $2178 \mathrm{~m}$ for technical reasons without having fulfilled its primary objective of penetrating the substratum of the lower basalt formation. The deepening of the Lopra-1/1A well in 1996 to 3565 m penetrated hyaloclastites, mostly lapilli tuffs, under the base of the lower basalt formation at about $2470 \mathrm{~m}$, but gave no definite clue as to the type of rocks occurring beneath the volcanics. The fact that the volcanics below the lower basalt formation were deposited subaqueously suggests that sediments were present in the area prior to the volcanic eruptions. Such sediments would probably be similar in age to the sediments exposed beneath the basalts in the Kangerlussuaq area in East Greenland reported by M. Larsen et al. (1999), sediments that probably give us the best clue as to what type of source rocks might exist beneath the volcanics at Lopra, since the palaeodistance between the Faroes block and central East Greenland was only 100-120 km before the break-up of the northern North Atlantic (Fig. 6). The close connection between the two areas is emphasised by the similarity in chemical composition of the oldest basalts on either side of the northern North Atlantic (L.M. Larsen et al. 1999).

The organic-rich rocks of the Kangerlussuaq area range in age from late Aptian to late Paleocene. They proved to be post-mature with respect to hydrocarbon generation 
at most localities examined by M. Larsen et al. (1999). However, a vitrinite reflectance value of Ro $=1.2$ measured on a late Paleocene lacustrine mudstone (TOC $=7 \%$ ) $22 \mathrm{~km}$ north of Nansen Fjord (Fig. 6) shows that source rocks with hydrocarbon generation potential do exist beneath the basalts in this area.

An estimate of organic matter maturation related to burial depth alone may be obtained from the Nansen Fjord area which was covered by approximately $6 \mathrm{~km}$ of volcanic rocks prior to uplift (L.M. Larsen et al. 1999). The total thickness of the Faroe Islands volcanics may exceed the $6.5 \mathrm{~km}$ presently known from exposures and drillings (Waagstein 2006, this volume); however, a more precise estimate of the thickness is difficult to give. It seems realistic to assume that possible source rocks below the Faroe Islands volcanic succession still have some potential for hydrocarbon generation, given the close connection between the two areas prior to continental split-up. Thus, the more or less continuous seepage of methane-rich gas into the open Lopra-1 well during 1983-1994 may originate from a highly mature source rock located beneath the volcanics in the area.

\section{Hydrocarbon migration from the Faroe-Shetland Basin}

Hydrocarbons may also have migrated into the Faroe Islands area from the Faroe-Shetland Basin, though little is known of the possible migration pathways. The Foinaven and Schiehallion oil fields, $160 \mathrm{~km}$ south-east of the Lopra-1 well, are the nearest known hydrocarbon occurrences around the Faroe Islands (Fig. 7), but hydrocarbons are likely to have been generated closer to the Faroe Islands in basalt-covered rift basins beneath the Faroe Shelf (Fig. 8).
Subsequently, these hydrocarbons may have migrated towards the Faroe Islands area via sandy turbidites located under the volcanics or via intrabasaltic sandstones. Redeposition of coarse-grained sediments onto the Faroe Shelf during mid-Paleocene uplift of East Greenland has been inferred by M. Larsen et al. (1999) but such sediments are not indicated on the geological profile of Fig. 7, which shows only strata recognised on seismic sections.

Since much of the Faroe-Shetland Basin is highly mature thermally, its lack of large gas accumulations has been explained by the presence of very oil-prone source rocks that have only little potential for later gas generation (Scotchman et al. 1998). This assumption was based on kinetic studies of Middle and Upper Jurassic kerogens from a number of exploration wells west of Shetland. If that is the case, the assumption that the gases observed in the Lopra-1 well came from the Faroe-Shetland Basin is not supported by observations from this basin obtained within a reasonable distance from the Faroe Islands.

\section{Conclusions}

Thermogenic gas, mostly methane, exists in the Lopra$1 / 1 \mathrm{~A}$ well in the hyaloclastites and in the more porous tuffaceous zones of the overlying lower basalt formation.

Chemical and isotopic data suggest that gases in the hyaloclastites were responsible for the more or less continuous seepage of gas into the original Lopra-1 well since 1983.

The location and the type of source rock that generated the gases observed in the Lopra-1 well are still uncertain. However, recent information on the pre-volcanic, organic-rich sediments of central East Greenland shows that these still have a potential for generating hydrocar-
Fig. 8. Geological profile modified from Spencer et al. (1999). Location shown on Fig. 7.

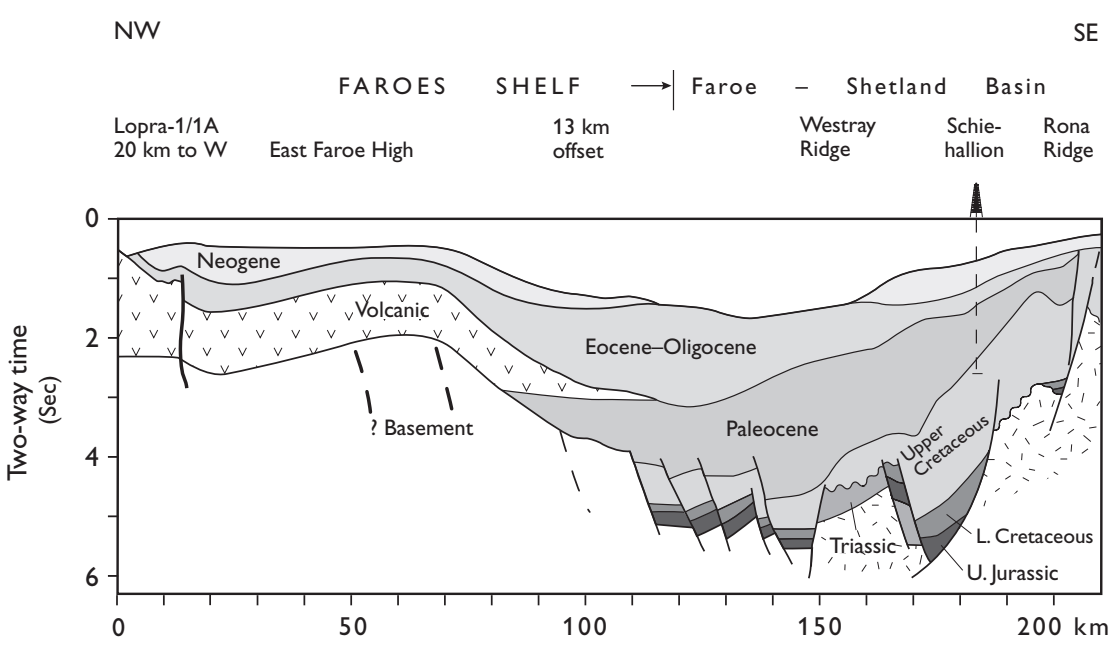


bons $(\mathrm{Ro}=1.2 \%)$ after having been buried below $6 \mathrm{~km}$ of volcanic rocks. Given the close connection demonstrated between central East Greenland and the Faroes block prior to continental break-up, it is probable that the source rock for the gases in Lopra-1/1A exists below the volcanics of the Faroe Islands area.

The possibility of migration of gas from the FaroeShetland Basin towards the Faroes cannot be excluded, although no evidence in support of this hypothesis has yet been found.

\section{Acknowledgements}

The two reviewers, Melody A. Rooney and Ger van Graas, are thankfully acknowledged for their careful review of the manuscript and valuable comments which helped improve the clarity of the paper.

\section{References}

Balling, N., Kristiansen, J.I. \& Saxov, S. 1984: Geothermal measurements from the Vestmanna-1 and Lopra-1 boreholes. In: Berthelsen, O., Noe-Nygaard, A. \& Rasmussen, J. (eds): The Deep Drilling Project 1980-1981 in the Faeroe Islands. Annales Societatis Scientiarum Faeroensis, Supplementum IX, 137-147. Tórshavn: Føroya Fródskaparfelag.

Berner, U. \& Faber, E. 1996: Empirical carbon isotope/maturity relationships for gases from algal kerogens and terrigenous organic matter, based on dry, open-system pyrolysis. Organic Geochemistry 24, 947-955.

Bojesen-Koefoed, J. \& Nytoft, H.P. 2006: Petroleum geochemistry of the deepened Lopra-1/1A re-entry well, Faroe Islands. Geological Survey of Denmark and Greenland Bulletin 9, 67-77 (this volume).

Coleman, D.D., Risatti, J.B. \& Schoell, M. 1981: Fractionation of carbon and hydrogen isotopes by methane-oxidizing bacteria. Geochimica et Cosmochimica Acta 45, 1033-1037.

Faber, E. 1987: Zur Isotopengeochemie gasförmiger Kohlenwasserstoffe. Erdöl, Erdgas, Kohle 103, 210-218.

Faber, E., Gerling, P. \& Dumke, I. 1988: Gaseous hydrocarbons of unknown origin found while drilling. Organic Geochemistry 13, 875-879.

Faber, E., Whiticar, J. \& Gerling, P. 1999: Comparison of hydrocarbons from unconventional sources: KTB, EPR and bit metamorphism. Geologisches Jahrbuch D107, 175-194.
Glassley, W.E. 2006: Mineralogical and thermodynamic constraints on Palaeogene palaeotemperature conditions during low-grade metamorphism of basaltic lavas recovered from the Lopra-1/1A deep hole, Faroe Islands. Geological Survey of Denmark and Greenland Bulletin 9, 109-118 (this volume).

Jacobsen, O.S. \& Laier, T. 1984: Analysis of gas and water samples from the Vestmanna-1 and Lopra-1 wells, Faeroe Islands. In: Berthelsen, O., Noe-Nygaard, A. \& Rasmussen, J. (eds): The Deep Drilling Project 1980-1981 in the Faeroe Islands. Annales Societatis Scientiarum Faeroensis, Supplementum IX, 149155. Tórshavn: Føroya Fródskaparfelag.

Konnerup-Madsen, J. 2006: A reconnaissance study of fluid inclusions in fracture-filling quartz and calcite from the Lopra-1/1A well, Faroe Islands. Geological Survey of Denmark and Greenland Bulletin 9, 119-122 (this volume).

Laier, T. 1999: The Siljan Deep Well - hydrocarbon gas results. Geologisches Jahrbuch D107, 153-163.

Laier, T., Nytoft H.P., Jørgensen, O. \& Isaksen, G.H. 1997: Hydrocarbon traces in the Tertiary of the Faeroe Islands. Marine and Petroleum Geology 14, 257-266.

Larsen, L.M., Waagstein, R., Pedersen, A.K. \& Storey, M. 1999: Trans-Atlantic correlation of the Palaeogene volcanic successions in the Faeroe Islands and East Greenland. Journal of the Geological Society (London) 156, 1081-1095.

Larsen, M., Hamberg, L., Olaussen, S., Nørgård-Pedersen, N. \& Stemmerik, L. 1999: Basin evolution in southern East Greenland: an outcrop analog for Cretaceous-Paleogene basins on the North Atlantic volcanic margin. American Association of Petroleum Geologists Bulletin 88, 1236-1261.

Rooney, M.A., Claypool, G.E. \& Chung, H.M. 1995: Modelling gas generation using carbon isotope ratios of natural gas hydrocarbons. Chemical Geology 126, 219-232.

Scotchman, I.C., Griffith, C.E., Holmes, A.J. \& Jones, D.M. 1998 The Jurassic petroleum system north and west of Britain: a geochemical oil source correlation study. Organic Geochemistry 29, 671-700.

Spencer, A.M., Birkeland, Ø., Knag, G.Ø. \& Fredsted, R. 1999: Petroleum systems of the Atlantic margin of northwest Europe. In: Fleet, A.J. \& Boldy, S.A.R. (eds): Petroleum geology of Northwest Europe: Proceedings of the $5^{\text {th }}$ Conference, 231-246. London: Geological Society.

Waagstein, R. 2006: Composite log from the Lopra-1/1A well, Faroe Islands. Geological Survey of Denmark and Greenland Bulletin 9, in pocket inside back cover (this volume).

Waagstein, R., Hald, N., Jørgensen, O., Nielsen, P.H., Noe-Nygaard, A., Rasmussen, J. \& Schönharting, G. 1984: Deep drilling on the Faeroe Islands. Bulletin of the Geological Society of Denmark 32, 133-138. 